
ISSN : 2615-1995, E-ISSN : 2615-0654

J. Madani., Vol. 3, No. 1, Maret 2020 (66 - 82)

C2018 Lembaga Kajian Demokrasi

\title{
Pengaruh Rekrutmen dan Seleksi Karyawan Terhadap Kinerja Karyawan Pada PT Trinitas Mulia Abadi Jakarta Utara
}

\author{
Veritia \\ Fakultas Ekonomi, Universitas Pamulang \\ veritia@gmail.com \\ Daning \\ Fakultas Ekonomi Universitas Pamulang \\ daning@leevierra.com
}

\begin{abstract}
Abstrak
Penelitian ini bertujuan untuk mengetahui secara positif dan signifikan pengaruh rekrutmen terhadap kinerja karyawan, pengaruh seleksi terhadap kinerja karyawan, dan pengaruh rekrutmen dan seleksi secara bersamasama terhadap kinerja karyawan. Metode yang digunakan dalam penelitian ini adalah kuantitatif deskriptif yang menjelaskan hubungan korelasional. Populasi dan sampel yang diteliti adalah karyawan PT Trinitas Mulia Abadi Jakarta Utara sebanyak 85 orang dengan menggunakan sampel jenuh. Nilai koefisien korelasi sebesar 0,642. Variabel rekrutmen $\left(X_{1}\right)$ dan seleksi $\left(X_{2}\right)$ secara simultan memiliki hubungan yang kuat terhadap kinerja karyawan $(Y)$. Nilai koefisien determinasi (R-Square) sebesar 0,412. Rekrutmen $\left(X_{1}\right)$ dan seleksi $\left(X_{2}\right)$ secara bersama-sama memiliki kontribusi pengaruh terhadap kinerja karyawan (Y) sebesar 41,2\%. Pada uji regresi linier berganda yaitu $Y=14,098+0,364 X_{1}+0,282 X_{2}$ yang artinya variabel rekrutmen dan seleksi searah dengan kinerja karyawan dan berpengaruh secara positif. Hasil uji signifikansi secara parsial untuk variabel rekrutmen $\left(X_{1}\right)$ diperoleh nilai $t_{\text {hitung }}>t_{\text {tabel }}$ atau $(6,481>1,989)$ dengan nilai signifikansi $(0,000<0,05)$, sedangkan untuk variabel seleksi $(X 2)$ diperoleh nilai $t_{\text {hitung }}>t_{\text {tabel }}$ atau $(5,852>1,989)$ dengan nilai signifikansi $(0,000<0,05)$ Dan pengujian secara simultan antara $X_{1}$ dan $X_{2}$ terhadap $Y$ diperoleh nilai $F_{\text {hitung }}>F_{\text {tabel }}$ atau $(28,745>3,110)$ yang diperkuat dengan nilai probability signifikansi sebesar $0,000<0,5$. Kesimpulan korelasi antara $X$ terhadap $Y$ adalah positif dan signifikan. maka terdapat pengaruh yang positif dan signifikan secara simultan antara $X_{1}$ dan $X_{2}$ terhadap $Y$. Saran sebaiknya perusahaan melakukan evaluasi untuk jumlah tenaga kerja yang dibutuhkan dan mempertimbangkan calon karyawan yang memiliki keahlian tertentu.
\end{abstract}

Kata Kunci : Rekrutmen, Seleksi dan Kinerja Karyawan

\begin{abstract}
This study aims to determine positively and significantly the effect of recruitment on employee performance, the effect of selection on employee performance, and the effect of recruitment and selection together on employee performance. The method used in this research is descriptive quantitative explaining correlational relationships. The population and sample studied were employees of PT. Trinitas Mulia Abadi North Jakarta as many as 85 people using saturated samples. Correlation coefficient value is 0.642 . The recruitment variables $\left(X_{1}\right)$ and selection $\left(\mathrm{X}_{2}\right)$ simultaneously have a strong relationship to employee performance $(Y)$. The coefficient of determination ( $R$-Square) is 0.412. Recruitment $\left(X_{1}\right)$ and selection $\left(X_{2}\right)$ together have an influence contribution to employee performance $(Y)$ of $41.2 \%$. In the multiple linear regression test that is $Y=14.098+0.364 X_{1}+$ $0.282 X_{2}$, which means that the recruitment and selection variables are in line with employee performance and have a positive effect. Partial significance test results for the recruitment variable $\left(X_{1}\right)$ obtained $t_{\text {value }}>t_{\text {table }}$ or
\end{abstract}


$(6.481>1.989)$ with a significance value $(0.000<0.05)$, while for the selection variable $\left(X_{2}\right)$ obtained $t_{\text {value }}>t_{\text {table }}$ or $(5.852>1,989)$ with a significance value $(0,000<0.05)$ And simultaneous testing between $X_{1}$ and $X_{2}$ against $Y$ obtained the value of $F_{\text {count }}>F_{\text {table }}$ or $(28.745>3.110)$ which is reinforced with a significance probability value of $0,000<0.5$. The conclusion between $X$ and $Y$ is positive and significant. then there is a positive and significant effect simultaneously between $X_{1}$ and $X_{2}$ on $Y$. Suggestions companies should evaluate the number of workers needed and consider prospective employees who have certain expertise.

Keywords : Recruitment, Selection and Employee Performance

\section{PENDAHULUAN}

Saat ini dunia bisnis mengalami persaingan yang sangat ketat, terutama dengan hadirnya teknologi sebagai sumber informasi. Perkembangan pesat di bidang ilmu pengetahuan dan teknologi, seperti teknologi komputer membuat dunia ini tidak bersekat. Hal ini juga telah mempengaruhi perkembangan bisnis global. Dimana perusahaan harus menyesuaikan sumber daya yang dimiliki termasuk sumber daya manusianya untuk menghadapi persaingan tersebut. Tenaga kerja sendiri merupakan aset organisasi jika dikelola dengan baik tujuan perusahaan akan tercapai

Pentingnya manajemen sumber daya manusia didukung oleh definisi beberapa para ahli, misalnya: Handoko (2011: 3), mengatakan "manajemen sumber daya manusia adalah penarikan, seleksi, pengembangan, pemeliharaan, dan penggunaan sumber daya manusia untuk mencapai baik tujuan-tujuan individu maupun organisasi”. Menurut Dessler (2015: 3), manajemen sumber daya manusia adalah "proses untuk memperoleh, melatih, menilai, dan mengompensasi karyawan dan untuk mengurus relasi tenaga kerja, kesehatan dan keselamatan, serta hal-hal yang berhubungan dengan keadilan". Sedangkan Simamora dalam Sutrisno (2015: 5), menyatakan bahwa "Manajemen sumber daya manusia adalah suatu pendayagunaan, pengembangan, penilaian, pemberian balas jasa dan pengelolaan individu anggota organisasi atau kelompok pekerja”. Agar tujuan dapat efisien dan efektif dalam pengelolaan maka perencanaan sumber daya manusia yang baik sangat diperlukan, terutama dalam hal pemilihan calon tenaga kerja dan proses seleksinya.

Perencanaan yang tepat dan matang akan memberikan manfaat semaksimal mungkin bagi perusahaan atau suatu organisasi. Menurut Siagian (2016: 44-48) "terdapat beberapa manfaat dari adanya perencanaan sumber daya manusia yang matang, yaitu: organisasi dapat memanfaatkan sumber daya yang ada secara lebih baik, produktivitas kerja dari tenaga yang ada dapat ditingkatkan, penentuan kebutuhan tenaga kerja di masa depan dari segi jumlah dan kualifikasi tepat sasaran, pengelolaan informasi ketenagakerjaan yang komprehensif, sumber data informasi dapat dijadikan penelitian untuk memberikan pemahaman sesuai situasi pasaran kerja dan perencanaan sumber daya manusia tersebut merupakan dasar bagi penyusunan program kerja."

Jadi perencanaan sumber daya manusia mutlak diperlukan terutama agar penerimaan karyawan sesuai dengan kriteria yang dibutuhkan. jika aktivitas perusahaan tidak didukung oleh sumber daya manusia yang sesuai dengan kriteria perusahaan, tentu akan menimbulkan dampak negatif bagi perusahaan. Misalnya tujuan perusahaan tidak tercapai, produktivitas menurun dan tidak tercainya efisiensi. Maka pengelolaan sumber daya manusia melalu perencanaan diperlukan agar menjamin calon tenaga kerja atau karyawan yang menduduki berbagai jabatan, fungsi, pekerjaan adalah sumber daya manusia yang tepat dan sesuai dengan kebutuhan perusahaan.

PT Trinitas Mulia Abadi dengan brand LeeVierra adalah organisasi atau perusahaan dibidang garmen yang memproduksi produk pakaian senam, pakaian zumba, pakaian yoga, pakaian renang dari mulai anak-anak sampai dewasa, serta menjual alat-alat sport dan asessories. Adapun bahan material yang digunakan seperti lycra, spandek dan berbagai jenis bahan katun. 
LeeVierra salah satu brand yang mengutamakan kualitas barang dan trend yang terbaru dalam model pakaian sport, dan barang yang di produksi oleh PT Trinitas Mulia Abadi akan dipasarkan di beberapa departement store dan showroom yang tersebar di seluruh Indonesia yang dijaga oleh Sales Promotion Girl (SPG).

Rekrutmen pada dasarnya merupakan proses mencari, menemukan, dan menarik pelamar untuk dipekerjakan dalam suatu perusahaan menurut Badriyah (2015: 87). Proses pengisian posisi yang kosong ini merupakan proses yang sangat penting, keakuratan dan adanya prosedur serta standar yang baik dapat meningkatkan efektifitas dan efisiensi operasional perusahaan. Proses ini juga menentukan kehandalan apakah mereka adalah the right man in the right place. Oleh karena job specification dan job description diperlukan dalam proses penempatan karyawan.

Sedangkan kegagalan dalam melakukan rekrutmen dan penempatan kerja akan mempengaruhi kinerja karyawan yang selanjutnya menjadi penghambat bagi proses pencapaian tujuan perusahaan. Sistem rekrutmen dan penempatan kerja yang dilakukan dengan tepat dan sesuai dengan kebutuhan bertujuan agar tercapainya tujuan perusahaan serta kesulitan dalam mencari dan melatih karyawan dapat dihindari. Terkadang proses rekrutmen yang dijalani tidak berjalan sesuai yang diharapkan. Jumlah calon tenaga kerja yang datang melamar sedikit, sehingga hal ini mempengaruhi kualitas tenaga kerja yang akan diseleksi nantinya. Di samping itu, terkadang kualifikasi pelamar yang diperoleh tidak sesuai dengan yang diharapkan.

Begitu juga yang terjadi di PT Trinitas Mulia Abadi. Berikut adalah tabel jumlah pelamar, jumlah karyawan yang dibutuhkan dan jumlah karyawan yang diterima dari tahun 2014 hingga 2017:

Dari tabel di bawah dapat dilihat bahwa dari tahun 2014 hingga 2017, jumlah pelamar terus meningkat yakni dari 39 hingga 57 pelamar. Namun hanya di tahun 2014 dan 2015 saja, jumlah pelamar yang diterima sesuai dengan kebutuhan yakni berjumlah 12 dan 15 karyawan saja. Sedangkan tahun 2016 dan 2017 terjadi ketidaksesuaian antara karyawan yang diterima dengan yang dibutuhkan. Yakni seharusnya dibutuhkan 10 karyawan di tahun 2016, hanya 7 saja yang terealisasi. Kemudian di tahun 2017, yang seharusnya membutuhkan 17 karyawan baru, hanya 15 yang terealisasi. Sehingga bisa dikatakan jumlah perekrutan karyawan belum sesuai dengan kebutuhan tenaga kerja di PT Trinitas Mulia Abadi.

\begin{tabular}{|c|c|c|c|}
\hline Tahun & Jumlah Pelamar & $\begin{array}{l}\text { Jumlah Karyawan } \\
\text { yang Dibutuhkan }\end{array}$ & $\begin{array}{r}\text { Jumlah Karyawan } \\
\text { yang Terealisasi }\end{array}$ \\
\hline 2014 & 39 & 12 & 12 \\
\hline 2015 & 42 & 15 & 15 \\
\hline 2016 & 48 & 10 & 7 \\
\hline 2017 & 57 & 17 & 15 \\
\hline
\end{tabular}

Untuk mengetahui jumlah kebutuhan tenaga kerja pada setiap divisi yang ada pada PT Trinitas Mulia Abadi dapat dilihat pada tabel berikut ini:

\begin{tabular}{l} 
Tabel 2. Data Jumlah Tenaga Kerja yang dibutuhkan dari setiap \\
Divisi yang ada Pada PT. Trinitas Mulia Abadi Tahun 2014-2017 \\
\begin{tabular}{|c|l|c|c|c|c|}
\hline No & Divisi Pekerjaan & $\mathbf{2 0 1 4}$ & $\mathbf{2 0 1 5}$ & $\mathbf{2 0 1 6}$ & $\mathbf{2 0 1 7}$ \\
\hline 1. & STAFF & 3 & 2 & 1 & 4 \\
\hline 2. & PRODUKSI & 3 & 5 & 2 & 5 \\
\hline 3. & SPG & 6 & 8 & 7 & 8 \\
\hline \multicolumn{7}{|c|}{ Jumlah } & 12 & 15 & 10 & 17 \\
\hline
\end{tabular} \\
\hline
\end{tabular}

Tabel di atas menunjukkan jumlah kebutuhan dari setiap divisi yakni, divisi Staff, divisi produksi dan divisi SPG. Di tahun 2014, Kebutuhan sudah sesuai yakni 12 karyawan dari tiap divisi (Staff (3), produksi (3) dan SPG (6). Begitu juga di tahun 2015, dimana staff memerlukan (2), produksi (5) dan SPG (8) karyawan dan jumlah 15 karyawan sesuai dengan kebutuhan. Namun di tahun 2016 dan 2017, jumlah yang dibutuhkan berjumlah 10 yakni Staff (1), produksi (2) dan SPG (7) jumlah yang dibutuhkan adalah 10 karyawan, yang terealisasi hanyalah 7 orang saja. Begitu juga di tahun 2017 kebutuhan karyawan adalah 17 orang yakni staff (4), produksi (5) dan SPG (8) sehingga seharusnya berjumlah 17 orang. Namun hanya 15 orang karyawan yang terealisasi.

Berdasarkan hal tersebut, PT Trinitas Mulia Abadi memiliki kekurangan jumlah tenaga 
kerja di tahun 2016 sebanyak 3 orang dan di tahun 2017 sebanyak 2 orang. Yang akhirnya, perusahaan menggunakan sumber internal yang ada yaitu dengan menempatkan karyawan lama pada jabatan yang dibutuhkan. Namun, hal ini menyebabkan adanya rangkap jabatan dan tidak adanya spesialisasi kerja serta karyawan menjadi tidak fokus pada pekerjaannya. Tentu hal ini dapat menurunkan kinerja karyawan tersebut dan juga menghambat karirnya.

Proses rekrutmen di setiap perusahaan atau organisasi berbeda-beda, karena disesuaikan dengan budaya, tujuan dan kebutuhan perusahaan itu sendiri. Namun umumnya, rekrutmen dilakukan berdasarkan kebutuhan jabatan. Untuk pelaksanaannya, selain divisisumber daya manusia bisa juga menggunakan penyedia jasa tenaga kerja (Outsider provider). Jika menggunakan jasa ini maka penyedia jasa melaksanakan proses rekrutmen sepenuhnya. Yang dilanjutkan dengan seleksi, penempatan karyawan hingga pemutusan hubungan kerja.

Departemen sumber daya manusia bertugas untuk mengisi jabatan dengan karyawan yang sesuai dan berkualitas untuk suatu pekerjaan. Jika karyawan dapat menjalankan fungsinya dengan tepat maka tentu akan menerima manfaat baik itu untuk dirinya, keluarganya juga perusahaan.

Setelah proses rekrutmen, proses yang tidak kalah pentingnyaadalah kegiatan seleksikaryawan. Kegiatan seleksi sangat penting karena hasil perekrutan tidak menjamin calon yang diperoleh sesuai dengan kriteria perusahaan. Seleksi dilakukan tidak hanya untuk memilih pegawai baru tetapi juga dapat untuk mempromosikan pegawai untuk naik ke jenjang karir yang lebih tinggi. Pentingnya seleksi mengakibatkannya harus dilakukan secara tepat dan cermat semua kegiatan perusahaan dapat dilaksanakan dengan baik sehingga tujuan perusahaan dapat tercapai. Pada PT. Trinitas Mulia Abadi setelah perekrutan seleksi karyawan juga dilakukan karena masih banyak karyawan yang masih bermasalah dengan tingkat kemampuan dan kinerjanya.

Berikut adalah tabel hasil seleksi pada 70 karyawan produksi di PT. Trinitas Mulia Abadi, adapun hasil seleksi karyawan sebagai berikut:

\begin{tabular}{|c|c|c|c|c|c|c|}
\hline \multicolumn{7}{|c|}{$\begin{array}{l}\text { Tabel 3. Seleksi Karyawan Divisi Produksi } \\
\text { Pada PT Trinitas Mulia Abadi } 2016\end{array}$} \\
\hline No & Seleksi Karyawan & $\begin{array}{c}\text { Sangat } \\
\text { Baik }\end{array}$ & Baik & $\begin{array}{c}\text { Cukup } \\
\text { Baik }\end{array}$ & $\begin{array}{l}\text { Kurang } \\
\text { Baik }\end{array}$ & Jumlah \\
\hline 1. & Keahlian & 38 & 21 & 9 & 2 & 70 \\
\hline 2. & Pengalaman & 15 & 23 & 18 & 14 & 70 \\
\hline 3. & Usia & 35 & 28 & 7 & 0 & 70 \\
\hline 4. & Pendidikan & 19 & 13 & 22 & 16 & 70 \\
\hline 5. & Jenis Kelamin & 56 & 7 & 4 & 3 & 70 \\
\hline
\end{tabular}

Dari tabel di atas memperlihatkan bahwa indikator yang digunakan dalam seleksi pekerja adalah pengalaman kerja dan pendidikan di PT Trinitas Mulia Abadi Divisi Produksi mendapat respon yang kurang baik terbanyak. Yakni untuk pengalaman terdapat 14 orang kurang berpengalaman dan 16 orang kurang baik dalam hal pendidikan.

Kinerja karyawan di sebuah perusahaan dapat disebabkan oleh berbagai faktor, salah satu penyebabnya sebuah perusahaan pasti memiliki karakteristik individu yang berbeda antara satu dengan yang lainnya. Perbedaan karakteristik individu karyawan inilah yang dapat menyebabkan perbedaan dalam hasil kinerja satu karyawan dengan karyawan yang lain. Perbedaan hasil kinerja antar karyawan berpengaruh pula pada pencapaian kinerja perusahaan secara keseluruhan. Agar pencapaian kinerja sesuai harapan, maka diperlukan pengembangan sumber daya manusia dimana pelaksanaan sistem rekrutmen yang efektif yang dilakukan harus sesuai dengan tujuan, peraturan dan cara yang benar.

PT Trinitas Mulia Abadi sendiri memiliki karyawan dalam operasional dan produksi barang jadi. PT Trinitas Mulia Abadi juga memiliki target pencapaian yang mengutamakan kinerja yang baik pada karyawannya, akan tetapi beberapa karyawan belum secara maksimal menjalankan tugas dan fungsinya sehingga belum memberikan kontribusi yang maksimal untuk perusahaan. Terlihat dari indikasi dilapangan bahwa masih adanya penurunan kinerja karyawan.

Terkait dengan menurunnya kinerja karyawan, berikut ini kondisi kinerja karyawan pada PT Trinitas Mulia Abadi yang dilihat dari hasil penilaian kinerja dari 2016 sampai 2017 dapat dilihat pada tabel 4 berikut ini: 


\begin{tabular}{|c|c|c|c|c|c|c|}
\hline \multicolumn{7}{|c|}{ Tabel 4. Rata-rata Hasil Penilaian Kinerja Karyawan } \\
\hline \multirow[b]{2}{*}{ PERILAKU KERJA } & \multicolumn{3}{|c|}{2016} & \multicolumn{3}{|c|}{2017} \\
\hline & $\begin{array}{c}\text { Bobot } \\
|\%|\end{array}$ & $\begin{array}{c}\text { Nilai } \\
\text { Caption }\end{array}$ & $\begin{array}{l}\text { Skor } \\
(\%)\end{array}$ & $\begin{array}{c}\text { Bobot } \\
(\%)\end{array}$ & $\begin{array}{c}\text { Nilai } \\
\text { Caption }\end{array}$ & $\begin{array}{l}\text { Skor } \\
(\%)\end{array}$ \\
\hline 1. Kedisiplinan & 10 & 75 & 7,5 & 10 & 65 & 6,5 \\
\hline 2. Tanggung jawab & 10 & 75 & 7,5 & 10 & 70 & 7 \\
\hline 3. Kerja sama & 10 & 80 & 8 & 10 & 70 & 7 \\
\hline 4. Kepemimpinan & 10 & 70 & 7 & 10 & 60 & 6 \\
\hline \multirow[b]{2}{*}{ HASIL KERJA } & \multicolumn{3}{|c|}{2016} & \multicolumn{3}{|c|}{2017} \\
\hline & $\begin{array}{c}\text { Bobot } \\
|\%|\end{array}$ & $\begin{array}{c}\text { Nilai } \\
\text { Caption }\end{array}$ & $\begin{array}{c}\text { Skor } \\
(\%)\end{array}$ & $\begin{array}{c}\text { Bobot } \\
(\%)\end{array}$ & $\begin{array}{c}\text { Nilai } \\
\text { Caption }\end{array}$ & $\begin{array}{l}\text { Skor } \\
(\%)\end{array}$ \\
\hline 1. Kualitas kerja & 20 & 80 & 16 & 20 & 70 & 14 \\
\hline 2. Kuantitas kerja & 20 & 80 & 16 & 20 & 70 & 14 \\
\hline $\begin{array}{l}\text { 3. Keterampilan } \\
\text { kerja }\end{array}$ & 20 & 80 & 16 & 20 & 80 & 16 \\
\hline JUMLAH & 100 & & 78 & 100 & & 70,5 \\
\hline
\end{tabular}

Berdasarkan tabel di atas dapat dilihat kondisi kinerja karyawan saat ini di PT. Trinitas Mulia Abadi mengalami penurunan dari tahun 2016 sampai 2017 disemua aspek dari $78 \%$ sampai $70,5 \%$.

Dalam menunjang kinerja karyawan yang baik pada PT. Trinitas Mulia Abadi, berikut dapat dilihat pada tabel 5 standar nilai kinerja karyawan:

\begin{tabular}{|}
\hline \multicolumn{3}{|c|}{ Tabel 5. Standar Nilai Kinerja Karyawan PT. Trinitas Mulia Abadi 2018} \\
\hline No & Nilai $\%$ K & Kategori \\
\hline 1 & $91-$ ke atas & Sangat baik \\
\hline 2 & $80-90$ & Baik \\
\hline 3 & $70-79$ & Cukup \\
\hline 4 & $61-69$ & Kurang \\
\hline 5 & 60 ke bawah & Buruk \\
\hline \multicolumn{2}{|c|}{ Sumber: Peraturan PT. Trinitas Mulia Abadi, 2018. } \\
\hline
\end{tabular}

PT Trinitas Mulia Abadi dituntut untuk selalu meningkatkan kinerja karyawan, agar perusahaan dapat terus bisa berkembang. Hal ini berdasarkan hasil pencapaian kinerja yang dapat dilihat pada tabel 4 di atas. Dan berdasarkan standar nilai yang ada di tabel di atas, kinerja pada tahun 2016 dan 2017 dalam kategori cukup saja.

Oleh Karena itu, karyawan harus mengoptimalisasikan kemampuannya untuk melakukan pekerjaannya dan bagian sumber daya manusia, dalam pelaksanaan perekrutan harus dapat meminimalisir hambatan yang ada. Mulai dari biaya yang terbatas, jumlah pelamar yang tidak sesuai dengan harapan, pilihan pelamar tidak sesuai dengan standar perusahaan dan hambatan-hambatan lain di luar perkiraan perusahaan.

Pelaksanaan yang terhambat karena adanya beberapa masalah dan alur rekrutmen yang kurang tepat, menyebabkan kurang maksimalnya proses tersebut. Proses rekrutmen dan seleksi haruslah sesuai dengan deskripsi pekerjaan supaya tidak menghambat proses pencapaian tujuan perusahaan. Proses rekrutmen dan seleksi yang belum optimal dan tidak sesuai dengan deskripsi pekerjaan dapat berpengaruh pada kinerja karyawan berawal dari kedisiplinan karyawan yang masih rendah hingga penurunan kualitas kinerja karyawan.

Mengingat sangat pentingnya proses rekrutmen dan seleksi diharapkan dengan adanya proses rekrutmen dan seleksi yang baik dan efektif akan berdampak pada perkembangan perusahaan kedepannya untuk memperoleh sumber daya yang berkualitas di PT Trinitas Mulia Abadi.

\section{METODE}

\section{Ruang Lingkup Penelitian Tempat Penelitian}

Penelitian ini dilakukan pada PT Trinitas Mulia Abadi yang berada di Jalan Gunung Sahari Raya No. 2 Komplek Marinatama No. 12B \& 15 Pademangan Jakarta Utara.

\section{Waktu Penelitian}

Waktu penelitian yang digunakan untuk penelitian Pengaruh Rekrutmen dan Seleksi Terhadap Kinerja Karyawan Pada PT Trinitas Mulia Abadi Jakarta Utara, dilakukan pada bulan Mei sampai dengan Juli 2018 hingga tercukupi kebutuhan data dan informasi.

\section{Sifat Penelitian}

Sifat penelitian yang digunakan dalam skripsi ini adalah kuantitatif deskriptif yang menjelaskan hubungan korelasional. Peneliti mendeskripsikan sebuah teori untuk landasan penelitian yang dipadukan dengan hasil survei kuesioner penelitian. 
"Kuantitatif merupakan suatu metode untuk meneliti populasi atau sampel tertentu, dimna pengambilan sampel secara acak, pengumpulan dara dan instrumennya dan analisis datanya bersifat statistik untuk menguji hipotesis yang ada." (Sugiyono, 2013: 13). Sedangkan "deskripstif merupakan metode untuk memberikan gambaran pada objek yang diteliti tanpa melakukan analisis dan membuat kesimpulan yang berlaku umum." (Sugiyono, 2012: 29).

\section{Metode Penentuan Populasi dan Sampel Populasi}

Sugiyono (2011:80) mendefinisikan "populasi adalah wilayah generalisasi yang terdiri atas obyek atau subyek yang mempunyai kualitas dan karakteristik yang ditetapkan oleh peneliti untuk dipelajari dan kemudian ditarik kesimpulannya". Berdasarkan pada tempat penelitian yang telah ditetapkan, maka populasi yang dijadikan objek dalam penelitian ini adalah seluruh karyawan yang bekerja pada PT Trinitas Mulia Abadi Jakarta Utara dengan jumlah karyawan sebanyak 85 orang.

\section{Sampel}

Menurut Sugiono (2015: 81) "sampel adalah sebagian atau wakil populasi yang di teliti. Apabila populasi besar, dan peneliti tidak mungkin mempelajari semua yang ada dalam populasi maka peneliti dapat menggunakan sampel yang di ambil dari populasi tersebut". Apa yang dipelajari dari sampel itu, kesimpulannya akan diberlakukan untuk populasi. Oleh karena itu sampel yang akan di ambil dari populasi harus betulbetul representatif. Sampel dalam penelitian ini berjumlah 85 orang. Dalam hal ini maka peneliti menggunakan sampel jenuh menurut Sugiyono (2015: 68) "sampel jenuh adalah teknik penentuan sampel bila semua anggota populasi digunakan sebagai sampel."

\section{Metode Pengumpulan Data}

Pengumpulan Data yang digunakan dalam penelitian ini terbagi kedalam 2 jenis yaitu data primer dan sekunder, yaitu:

\section{Data Primer (Primery Data)}

Data primer adalah sumber data penelitian yang diperoleh secara langsung dari sumber asli (tidak melalui media perantara). Data primer ini dikumpulkan melalui observasi dan kuesioner (angket).

a. Observasi

Observasi menurut Sugiyono (2015: 145) "Teknik pengumpulan data dilakukan dengan observasi digunakan bila, penelitian berkenaan dengan perilaku manusia, proses kerja, gejala-gejala alam dan bila responden yang diamati tidak terlalu besar". Data yang akan terkumpul dari observasi berupa informasi keaktifan kinerja karyawan pada PT Trinitas Mulia Abadi Jakarta Utara.

b. Kuesioner (angket)

"Kuesioner merupakan penelitian dengan cara mengajukan daftar pernyataan langsung kepada responden. Skala yang digunakan adalah skala likert (likert scale), karena skala likert digunakan untuk mengukur sikap, pendapat dan persepsi seseorang tentang kejadian atau gejala sosial." (Sugiyono, 2015: 93).

\section{Data Sekunder (Secondary Data)}

Data sekunder adalah sumber data penelitian yang diperoleh peneliti secara tidak langsung melalui media perantara. Adapun data sekunder yang digunakan yaitu:

a. Studi Pustaka

Teknik pengumpulan data dilakukan dengan cara peneliti mendalami, menelaah, mencermati, dan mengidentifikasi pengetahuan yang ada dalam kepustakaan (sumber bacaan, buku-buku referensi atau hasil penelitian lain) untuk menunjang penelitian.

\section{b. Dokumentasi}

Pengumpulan data dilakukan dengan cara mengutip langsung data yang diperoleh dari PT Trinitas Mulia Abadi Jakarta Utara yang terdiri dari profil, sejarah, visi dan misi perusahaan. 


\section{HASIL dan PEMBAHASAN}

\section{Pengertian Rekrutmen}

Menurut Mardianto (2014: 8) "Rekrutmen diartikan sebagai suatu proses untuk mendapatkan calon karyawan yang memiliki kemampuan yang sesuai dengan kualifikasi dan kebutuhan suatu organisasi/perusahaan."

Rekrutmen menurut Marwansyah (2012: 106) adalah proses menarik orang-orang atau pelamar yang mempunyai minat dan kualifikasi yang tepat untuk mengisi posisi atau jabatan tertentu.

Sedangkan Zainal. V.R \& Ramly, M dkk (2015: 118) mengartikan bahwa rekrutmen adalah suatu proses menentukan dan menarik pelamar yang mampu untuk bekerja dalam suatu perusahaan.

Berdasarkan dari beberapa pengertian di atas dapat disimpulkan bahwa rekrutmen adalah usaha atau suatu proses untuk menarik atau mendapatkan pelamar atau calon karyawan yang efektif dan efisien serta memiliki kemapuan yang sesuai dengan kebutuhan perusahaan untuk membantu tercapainya tujuan perusahaan.

\section{Indikator Rekrutmen}

Menurut Hasibuan (2011: 41) indikatorindikator dari variabel proses rekrutmen antara lain:

a. Dasar Perekrutan

Harus berpedoman pada spesifikasi pekerjaan yang telah ditentukan untuk menduduki jabatan tersebut

b. Sumber Perekrutan

1. Sumber Internal

Memutasikan karyawan yang memenuhi standar dari jabatan yang lowong tersebut.

2. Sumber Eksternal

Karyawan yang mengisi jabatan yang lowong direkrut dari sumber-sumber tenaga kerja di luar perusahaan.

c. Metode Perekrutan

1. Metode Tertutup

Perekrutan hanya diinformasikan kepada para karyawan atau orang-orang tertentu saja.

2. Metode Terbuka
Perekrutan diinformasikan secara luas dengan memasang iklan dan menyebar luaskan ke masyarakat.

\section{Pengertian Seleksi}

Proses seleksi dimulai setelah kumpulan para pelamar yang memenuhi syarat, didapatkan melalui penarikan. Proses ini melibatkan serangkaian tahap yang menambah kompleksitas dan waktu sebelum keputusan pengadaan personalia diambil.

Untuk lebih jelasnya penulis mengemukakan beberapa definisi seleksi menurut para ahli, sebagai berikut:

a. Zainal, V.R \& Ramly, M, dkk (2015: 126) "mendefinisikan seleksi adalah proses pemilihan karyawan setelah proses rekrutmen selesai dilaksanakan."

b. Ardana, I., K (2012: 69) "seleksi tenaga kerja adalah suatu kegiatan untuk memenuhi syarat-syarat yang telah ditetapkan oleh perusahaan".

c. Menurut Manullang (2011: 54), "seleksi adalah suatu proses pemilihan beberapa orang dari sekumpulan orang-orang dengan preferensi tertentu dan seleksi ini bertujuan untuk mencari atau memilih tenaga kerja yang sesuai dengan persyaratan atau kualifikasi jabatan tertentu."

Dari beberapa definisi di atas maka dapat disimpulkan bahwa seleksi adalah proses pemilihan dari sekumpulan orang-orang atau pelamar yang paling sesuai dengan kebutuhan perusahaan untuk menempati posisi atau jabatan tertentu setelah dilaksanakannya proses reksrutmen dan melalui beberapa rangkaian kegiatan yang digunakan untuk menentukan pelamar tersebut diterima atau ditolak.

\section{Indikator Seleksi Karyawan}

Indikator seleksi karyawan menurut $\mathrm{Ma}$ nullang (2011: 54) terdiri dari:

1. Keahlian

Keahlian merupakan salah satu kualifikasi utama yang menjadi dasar dalam proses seleksi, kecuali bagi jabatan yang tidak memerlukan keahlian. 
1. Technical Skill, yaitu keahlian teknik yang harus dimiliki para karyawan pelaksana.

2. Human Skill, yaitu keahlian yang dimiliki oleh mereka yang akan memimpin beberapa orang bawahan.

3. Conceptual Skill, yaitu keahlian yang harus dimiliki oleh mereka yang akan memangku jabatan pucuk pemimpin sebagai orang yang mampu mengkoordinasi berbagai aktivitas untuk mencapai tujuan organisasi.

b. Pengalaman

Pengalaman dapat menunjukkan apa yang dapat dikerjakan oleh calon pegawai pada saat dia melamar. Umumnya perusahaan-perusahaan lebih cenderung memilih tenaga kerja yang berpengalaman. Pengalaman saja tidak dapat digunakan menentukan kemampuan seorang pelamar dalam menyelesaikan tugas dengan baik. Pada taraf permulaan memang mereka yang mempunyai pengalaman tidak membutuhkan bimbingan dan pengawasan, namun secara sistematis maka mereka mempunyai intelejensia yang baik dari mereka yang berpengalaman tetapi tidak mempunyai intelejensia yang baik.

c. Usia

Umumnya perusahaan tidak begitu saja menerima calon pelamar yang berusia muda maupun yang berusia lanjut. Mereka yang mempunyai usia lebih lanjut cenderung mempunyai tenaga fisik relatif kecil dan terbatas, meskipun mereka ini umumnya sudah memiliki pengalaman. Pada umumnya suatu perusahaa menolak memperkerjakan mereka yang berusia lanjut karena alasan-alasan berikut:

1. Terlalu lambat bekerja

2. Kurang kreatif dibandingkan dengan tenaga kerja yang berusia muda

3. Sukar mendidiknya

4. Sering mangkir karena alasan kesehatan

5. Sering sakit atau kurang sehat dibandingkan dengan tenaga kerja yang berusia muda"

d. Pendidikan

Pendidikan sering digandeng dengan latihan, umumnya dianggap dapat menunjukkan kesanggupan dari pelamar. Dengan demikian misalnya di Negara-negara yang sudah maju, pendidikan universitas sering merupakan salah satu dari kualifikasi dari seorang calon yang akan memangku jabatan manajer, terlebih-lebih jabatan manajer tingkat menengah dan tingkat tinggi.

e. Jenis Kelamin

Jenis kelamin sering pula diperhatikan sebagai dasar dalam mengadakan seleksi, terlebih untuk jabatan teretentu. Dalam zaman emansipasi sekarang, maka terbuka pintu yang luas bagi kaum wanita untuk memangku jabatan-jabatan yang terdahulu hanya diperuntukan kaum pria.

\section{Pengertian Kinerja}

Menurut Hasibuan (2012: 94) "Kinerja adalah hasil kerja yang dicapai seseorang dalam melaksanakan tugas-tugas yang dibebankan kepadanya yang didasarkan atas kecakapan, pengalaman, kesungguhan, serta waktu."

Menurut Armstrong dan Baron dalam Wibowo (2012: 7) "Kinerja adalah hasil pekerjaan yang mempunyai hubungan kuat dengan tujuan strategi organisasi, kepuasan konsumen, dan memberikan kontribusi pada ekonomi. Dengan demikian kinerja adalah tentang melakukan pekerjaan dan hasil dari pekerjaan tersebut."

Dessler (2011: 357), menyatakan bahwa manajemen kinerja merupakan proses yang berlangsung secara berkelanjutan.

"Performance management is the continous process to identitying, measuring and developing the performance of individuals, teams and aligning their performance with the organization goals." - (Manajemen kinerja merupakan suatu proses berkelanjutan untuk mengidentifikasi, menghitung, dan mengembangkan hasil kerja dan individu-individu, tim, dan menghubungkan kinerja tersebut dengan tujuan organisasi.)"

Berdasarkan beberapa definisi di atas mengenai kinerja, peneliti menyimpulkan bahwasannya kinerja adalah hasil kerja seseorang yang sudah dikerjakan sesuai dengan tanggung jawab yang diberikan kepadanya pada periode waktu tertentu. 


\section{Indikator Kinerja}

Menurut Wirawan (2011: 53) "bahwa sebelum menentukan indikator kinerja terlebih dahulu mengelompokkan masing-masing indikator ke dalam dimensi kinerja." Dimensi kinerja adalah" unsur-unsur dalam pekerjaan yang menunjukkan kinerja. Untuk mengukur kinerja, dimensi-dimensi kinerja dikembangkan menjadi indikator kinerja "(Wirawan, 2011: 54). Jadi indikator kinerja digunakan untuk membuat instrumen pernyataan untuk mengukur kinerja karyawan.

Menurut Mangkunegara (2011: 75) dimensi dan indikator kinerja adalah sebagai berikut:

a. Kualitas

Kualitas kerja adalah seberapa baik seorang karyawan mengerjakan apa yang seharusnya dikerjakan.

b. Kuantitas

Kuantitas kerja adalah seberapa lama seorang pegawai bekerja dalam satu harinya. Kuantitas kerja ini dapat dilihat dari kecepatan kerja setiap pegawai itu masing-masing.

c. Tanggung Jawab

Tanggung jawab terhadap pekerjaan adalah kesadaran akan kewajiban karyawan untuk melaksanakan pekerjaan yang diberikan perusahaan.

d. Kerjasama

Pegawai mampu bekerja sama dengan rekan kerjanya dalam menyelesaikan tugas yang diberikan oleh organisasi atau instansi.

e. Insiatif

Pegawai mempunyai kemampuan dalam mengerjakan tugas dan mempunyai inisiatif.

\section{Distribusi Hasil Pengolahan Kuesioner}

\section{Variabel Rekrutmen $\left(\mathbf{X}_{1}\right)$}

Berdasarkan kuesioner yang disebarkan kepada 85 responden, maka diperoleh jawaban tentang variabel rekrutmen secara umum mendapatkan respon yang "Baik" hal ini dapat dilihat dari rata-rata nilai yang diperoleh untuk variabel rekrutmen sebesar 3,87 yang terdapat pada rentang skala antara 3,40-4,19 dengan kriteria "Baik".

Hal tersebut didukung oleh nilai rata- rata setiap indikator yaitu indikator dasar perekrutan dengan nilai rata-rata 3,84 (Baik), indikator sumber perekrutan dengan nilai rata-rata sebesar 3,87 (Baik), dan indikator metode perekrutan sebesar 3,89 (Baik). Nilai rata-rata tertinggi terdapat pada indikator metode rekrutmen sebesar 3,96 termasuk dalam kategori "Baik" yang berarti bahwa perusahaan sudah menjalankan metode perekrutan karyawan dengan baik.

\section{Variabel Seleksi $\left(\mathrm{X}_{2}\right)$}

Berdasarkan kuesioner yang disebarkan kepada 85 responden, maka diperoleh jawaban tentang variabel seleksi secara umum mendapatkan respon yang "Baik" hal ini dapat dilihat dari rata-rata nilai yang diperoleh untuk variabel seleksi sebesar 3,79 yang terdapat pada rentang skala antara 3,404,19 dengan kriteria "Baik".

Hal tersebut didukung oleh nilai ratarata setiap indikator yaitu indikator keahlian dengan nilai rata-rata 3,70 (Baik), indikator pengalaman dengan nilai rata-rata sebesar 3,78 (Baik), indikator usia sebesar 3,72 (Baik), indikator pendidikan sebesar 3,88 (Baik), dan indikator jenis kelamin sebesar 3,89 (Baik). Nilai rata-rata tertinggi terdapat pada indikator jenis kelamin sebesar 4,07 termasuk dalam kategori "Baik" yang berarti bahwa dalam perusahaan tersebut karyawan pria akan cenderung lebih berprestasi dibandingkan karyawan wanita.

\section{Variabel Kinerja (Y)}

Berdasarkan kuesioner yang disebarkan kepada 85 responden, maka diperoleh jawaban tentang variabel kinerja secara umum mendapatkan respon yang "Baik" hal ini dapat dilihat dari rata-rata nilai yang diperoleh untuk variabel kinerja sebesar 3,88 yang terdapat pada rentang skala antara 3,404,19 dengan kriteria "Baik".

Hal tersebut didukung oleh nilai ratarata setiap indikator yaitu indikator kualitas dengan nilai rata-rata 3,66 (Baik), indikator kuantitas dengan nilai rata-rata sebesar 3,95 (Baik), indikator tanggung jawab sebesar 3,81 (Baik), indikator kerjasama sebesar 4,00 
(Baik), dan indikator inisiatif sebesar 4,00 (Baik). Nilai rata-rata tertinggi terdapat pada indikator kuantitas sebesar 4,07 termasuk dalam kategori "Baik" yang berarti bahwa karyawan yang bekerja pada perusahaan sudah baik dan dapat memiliki target dalam pekerjaannya.

\section{Pengujian Instrumen dan Data Penelitian}

Pengujian instrumen diperlukan untuk mengetahui bahwa variabel yang diteliti memiliki fungsi sebagai alat pembuktian.

\section{Uji Validitas}

Pengujian validitas digunakan untuk mengetahui kelayakan dari setiap butir pertanyaan dalam penelitian, apakah valid atau tidak dengan kriteria:

a. Jika nilai $\mathrm{r}_{\text {hitung }}>\mathrm{r}_{\text {tabel }}$ maka butir pertanyaan dikatakan valid.

b. Jika nilai $\mathrm{r}_{\text {hitung }}<\mathrm{r}_{\text {tabel }}$ maka butir pertanyaan dikatakan tidak valid.

Taraf signifikansi $\alpha=0,05$ dengan tingkat kepercayaan pengujiannya $95 \%$.

Berikut ini hasil perhitungan uji validitas setiap variabel yang digunakan, yaitu:

a. Pengujian Validitas Untuk Variabel Rekrutmen $\left(\mathrm{X}_{1}\right)$

\begin{tabular}{|c|c|c|c|}
\hline \multicolumn{4}{|c|}{ Tabel 6. Uji Validitas Variabel Rekrutmen (X) } \\
\hline Penyataan & $\mathbf{r}_{\text {hitung }}$ & $r_{\text {tabel }}$ & Keputusan \\
\hline 1. Menetapkan spesifikasi pekerjaan & 0.387 & 0.213 & Valid \\
\hline 2. Memahami spesifikasi pekerjaan & 0.400 & 0.213 & Valid \\
\hline 3. Analisis jabatan sesuai dengan kriteria & 0.317 & 0.213 & Valid \\
\hline 4. Perekrutan dari internal & 0.554 & 0.213 & Valid \\
\hline 5. Perekrutan dari eksternal & 0.775 & 0.213 & Valid \\
\hline 6. Perekrutan karyawan berprestasi & 0.464 & 0.213 & Valid \\
\hline $\begin{array}{l}\text { 7. Perekrutan dengan teknologi informasi } \\
\text { yang baik }\end{array}$ & 0.717 & 0.213 & Valid \\
\hline $\begin{array}{l}\text { 8. Perekrutan menggunakan media online } \\
\text { dan offline }\end{array}$ & 0.754 & 0.213 & Valid \\
\hline $\begin{array}{l}\text { 9. Informasikan perekrutan kepada karyawan } \\
\text { tertentu }\end{array}$ & 0.740 & 0.213 & Valid \\
\hline 10. Proses rekrutmen berjalan efektif & 0.449 & 0.213 & Valid \\
\hline \multicolumn{4}{|c|}{ Sumber: Data primer diolah, 2018} \\
\hline
\end{tabular}

Berdasarkan data tabel 6 di atas, dapat dilihat bahwa dari 10 butir pernyataan untuk variabel rekrutmen $\left(\mathrm{X}_{1}\right)$ semua butir pernyataan dinyatakan valid, dimana semua item pernyataan memiliki nilai corrected item total correlation lebih besar dari 0,213 atau $\mathrm{r}_{\text {hitung }}>\mathrm{r}_{\text {tabel }}$

\section{b. Pengujian Validitas Untuk Variabel Seleksi} $\left(\mathrm{X}_{2}\right)$

\begin{tabular}{|l|c|c|c|}
\hline \multicolumn{4}{|c|}{ Tabel 7. Uji Validitas Variabel Seleksi $\left(\mathbf{X}_{\mathbf{2}}\right)$} \\
\hline $\begin{array}{l}\text { P. Keahlian tertentu akan sangat } \\
\text { dipertimbangkan }\end{array}$ & $\mathbf{r}_{\text {hitung }}$ & $\mathbf{r}_{\text {tabel }}$ & Keputusan \\
\hline 2. Keahlian meningkatkan kuantitas kerja & 0.557 & 0.213 & Valid \\
\hline 3. Pelamar harus memiliki pengalaman & 0.466 & 0.213 & Valid \\
\hline $\begin{array}{l}\text { 4. Perusahaan membutuhkan pelamar } \\
\text { berpengalaman }\end{array}$ & 0.584 & 0.213 & Valid \\
\hline 5. Tes kesehatan penting untuk dilakukan & 0.552 & 0.213 & Valid \\
\hline $\begin{array}{l}\text { 6. Pelamar dengan usia lebih muda lebih } \\
\text { dominan }\end{array}$ & 0.484 & 0.213 & Valid \\
\hline $\begin{array}{l}\text { 7. Latar belakang pendidikan sebagai syarat } \\
\text { utama }\end{array}$ & 0.463 & 0.213 & Valid \\
\hline 8. Pendidikan pelamar minimal S1 & 0.262 & 0.213 & Valid \\
\hline $\begin{array}{l}\text { 9. Jenis kelamin tidak dibedakan untuk } \\
\text { pelamar }\end{array}$ & 0.538 & 0.213 & Valid \\
\hline 10. Karyawan pria cenderung berprestasi & 0.653 & 0.213 & Valid \\
\hline \begin{tabular}{l} 
Sumber: Data primer diolah, 2018 \\
\hline
\end{tabular} & & \\
\hline
\end{tabular}

Berdasarkan data tabel 7 di atas, dapat dilihat bahwa dari 10 butir pernyataan untuk variabel seleksi $\left(\mathrm{X}_{2}\right)$ disimpulkan bahwa semua butir pernyataan dinyatakan valid, hal ini dibuktikan dengan semua item-item pernyataan memiliki nilai corrected item total correlation lebih besar dari nilai $r_{\text {tabel }} 0,213$. Untuk itu kuesioner yang digunakan layak untuk diolah data penelitian.

\section{c. Pengujian Validitas Untuk Variabel Kinerja Karyawan (Y)}

\begin{tabular}{|l|c|c|c|}
\hline \multicolumn{4}{|c|}{ Tabel 8. Uji Validitas Variabel Kinerja Karyawan (Y) } \\
\hline & $\mathbf{r}_{\text {hitung }}$ & $\mathbf{r}_{\text {tabel }}$ & Keputusan \\
\hline 1. Karyawan menghasilkan output yang baik & 0.452 & 0.213 & Valid \\
\hline 2. Karyawan memiliki keterampilan & 0.505 & 0.213 & Valid \\
\hline 3. Disiplin karyawan baik & 0.273 & 0.213 & Valid \\
\hline 4. Karyawan menetapkan target kerja & 0.520 & 0.213 & Valid \\
\hline $\begin{array}{l}\text { 5. Karyawan memiliki komitmen dalam } \\
\text { bekerja }\end{array}$ & 0.524 & 0.213 & Valid \\
\hline $\begin{array}{l}\text { 6. Karyawan memiliki tanggung jawab yang } \\
\text { baik }\end{array}$ & 0.449 & 0.213 & Valid \\
\hline 7. Terbuka dengan perbedaan pendapat & 0.606 & 0.213 & Valid \\
\hline 8. Hubungan dengan rekan kerja baik & 0.549 & 0.213 & Valid \\
\hline 9. Karyawan memiliki inisiatif dalam bekerja & 0.678 & 0.213 & Valid \\
\hline 10. Melaksanakan tugas dengan terampil & 0.508 & 0.213 & Valid \\
\hline
\end{tabular}

Berdasarkan data tabel 8 di atas, dapat dilihat bahwa dari 10 butir pernyataan untuk variabel 
kinerja karyawan (Y) semua butir pernyataan dinyatakan valid, hal ini dibuktikan dengan semua item pernyataan memiliki nilai rhitung $>$ rtabel $(0,213)$.

\section{Uji Reliabilitas}

Uji reliabilitas dimaksudkan untuk menguji kehandalan atau kestabilan jawaban dari responden. Kriteria dalam pengambilan keputusan reliable dan tidaknya jawaban pernyataan adalah sebagai berikut:

a. Jika nilai $\mathrm{r}_{\text {hitung }}>\mathrm{r}_{\text {tabel }}$ maka butir pernyataan dikatakan reliable.

b. Jika nilai $\mathrm{r}_{\text {hitung }}<\mathrm{r}_{\text {tabel }}$ maka butir pernyataan dikatakan tidak reliable.

Taraf signifikansi $\alpha=0,05$ (5\%) dengan tingkat kepercayaan pengujiannya adalah 95\%.

Berikut ini hasil perhitungan uji reliabilitas pada masing-masing variabel, sebagai berikut:

\section{a. Pengujian Reliabilitas Untuk Variabel Rekrutmen $\left(\mathrm{X}_{1}\right)$}

Berikut ini hasil pengujian reliabilitas variabel rekrutmen $\left(\mathrm{X}_{1}\right)$ :

\begin{tabular}{|c|c|c|c|}
\hline Penyataan & $r_{\text {hitung }}$ & $r_{\text {tabel }}$ & Keputusan \\
\hline 1. Menetapkan spesifikasi pekerjaan & 0.761 & 0.213 & Reliabel \\
\hline 2. Memahami spesifikasi pekerjaan & 0.749 & 0.213 & Reliabel \\
\hline 3. Analisis jabatan sesuai dengan kriteria & 0.763 & 0.213 & Reliabel \\
\hline 4. Perekrutan dari internal & 0.733 & 0.213 & Reliabel \\
\hline 5. Perekrutan dari eksternal & 0.686 & 0.213 & Reliabel \\
\hline 6. Perekrutan karyawan berprestasi & 0.742 & 0.213 & Reliabel \\
\hline $\begin{array}{l}\text { 7. Perekrutan dengan teknologi informasi } \\
\text { yang baik }\end{array}$ & 0.698 & 0.213 & Reliabel \\
\hline $\begin{array}{l}\text { 8. Perekrutan menggunakan media online } \\
\text { dan offline }\end{array}$ & 0.693 & 0.213 & Reliabel \\
\hline $\begin{array}{l}\text { 9. Informasikan perekrutan kepada karyawan } \\
\text { tertentu }\end{array}$ & 0.694 & 0.213 & Reliabel \\
\hline 10. Proses rekrutmen berjalan efektif & 0.746 & 0.213 & Reliabel \\
\hline \multicolumn{4}{|c|}{ Sumber: Data primer diolah, 2018} \\
\hline
\end{tabular}

Berdasarkan hasil uji reliabilitas pada tabel 9 di atas, disimpulkan reliabel, hal itu dibuktikan dengan nilai $r_{\text {hitung }}>r_{\text {tabel }}(0,213)$. Dengan demikian data layak untuk diteruskan pada penelitian ini.

\section{b. Pengujian Reliabilitas Untuk Variabel Seleksi $\left(\mathrm{X}_{2}\right)$}

Berikut ini hasil pengujian reliabilitas variabel seleksi $\left(\mathrm{X}_{2}\right)$ :

\begin{tabular}{|l|c|c|c|}
\hline \multicolumn{4}{|c|}{ Tabel 10. Hasil Uji Reliabilitas Variabel Seleksi (X) } \\
\hline \multicolumn{1}{|c|}{ Penyataan } & $\mathbf{r}_{\text {hitung }}$ & $\mathbf{r}_{\text {tabel }}$ & Keputusan \\
\hline $\begin{array}{l}\text { 1. Keahlian tertentu akan sangat } \\
\text { dipertimbangkan }\end{array}$ & 0.677 & 0.213 & Reliabel \\
\hline 2. Keahlian meningkatkan kuantitas kerja & 0.658 & 0.213 & Reliabel \\
\hline 3. Pelamar harus memiliki pengalaman & 0.693 & 0.213 & Reliabel \\
\hline $\begin{array}{l}\text { 4. Perusahaan membutuhkan pelamar } \\
\text { berpengalaman }\end{array}$ & 0.667 & 0.213 & Reliabel \\
\hline 5. Tes kesehatan penting untuk dilakukan & 0.674 & 0.213 & Reliabel \\
\hline $\begin{array}{l}\text { 6. Pelamar dengan usia lebih muda lebih } \\
\text { dominan }\end{array}$ & 0.686 & 0.213 & Reliabel \\
\hline $\begin{array}{l}\text { 7. Latar belakang pendidikan sebagai syarat } \\
\text { utama }\end{array}$ & 0.688 & 0.213 & Reliabel \\
\hline 8. Pendidikan pelamar minimal S1 & 0.723 & 0.213 & Reliabel \\
\hline $\begin{array}{l}\text { 9. Jenis kelamin tidak dibedakan untuk } \\
\text { pelamar }\end{array}$ & 0.675 & 0.213 & Reliabel \\
\hline 10. Karyawan pria cenderung berprestasi & 0.652 & 0.213 & Reliabel \\
\hline \multicolumn{3}{|c|}{ Sumber: Data primer diolah, 2018 } \\
\hline
\end{tabular}

Berdasarkan data tabel 10 di atas, dapat dilihat bahwa dari 10 butir pernyataan untuk variabel seleksi $\left(\mathrm{X}_{2}\right)$ semua butir pernyataan dinyatakan reliabel, dimana semua item pernyataan memiliki nilai $\mathrm{r}_{\text {hitung }}>\mathrm{r}_{\text {tabel }}(0,213)$.

\section{c. Pengujian Reliabilitas Untuk Variabel Kinerja Karyawan (Y)}

Berikut hasil pengujian reliabilitas variabel Kinerja Karyawan (Y):

\begin{tabular}{|c|c|c|c|}
\hline Penyataan & $r_{\text {hitung }}$ & $r_{\text {tabel }}$ & Keputusan \\
\hline 1. Karyawan menghasilkan output yang baik & 0.658 & 0.213 & Reliabel \\
\hline 2. Karyawan memiliki keterampilan & 0.661 & 0.213 & Reliabel \\
\hline 3. Disiplin karyawan baik & 0.692 & 0.213 & Reliabel \\
\hline 4. Karyawan menetapkan target kerja & 0.648 & 0.213 & Reliabel \\
\hline $\begin{array}{l}\text { 5. Karyawan memiliki komitmen dalam } \\
\text { bekerja }\end{array}$ & 0.641 & 0.213 & Reliabel \\
\hline $\begin{array}{l}\text { 6. Karyawan memiliki tanggung jawab yang } \\
\text { baik }\end{array}$ & 0.652 & 0.213 & Reliabel \\
\hline 7. Terbuka dengan perbedaan pendapat & 0.621 & 0.213 & Reliabel \\
\hline 8. Hubungan dengan rekan kerja baik & 0.633 & 0.213 & Reliabel \\
\hline 9. Karyawan memiliki inisiatif dalam bekerja & 0.603 & 0.213 & Reliabel \\
\hline 10. Melaksanakan tugas dengan terampil & 0.643 & 0.213 & Reliabel \\
\hline \multicolumn{4}{|c|}{ Sumber: Data primer diolah, 2018} \\
\hline
\end{tabular}

Berdasarkan hasil pengolahan data tabel 11 di atas, diketahui bahwa masing-masing item pernyataan variabel kinerja karyawan $(\mathrm{Y})$ memiliki nilai $\mathrm{r}_{\text {hitung }}>\mathrm{r}_{\text {tabel }}(0,213)$. Dengan demikian instrumen dinyatakan reliabel.

\section{Uji Kelayakan Data (Asumsi Klasik)}

a. Uji Normalitas

"Apakahmodel regresi,variabeldependen 
dan variabel independen terdistribusi normal atau tidak normal diperlukan uji normalitas. Untuk memastikan asumsi bahwa persamaan tersebut terdistribusi normal dilakukan melalui pendekatan alat ukur perhitungan residual variabel bebas (Y)." Uji normalitas dalam penelitian ini menggunakan residual variabel yaitu Kolmogorov-Smirnov Test dengan syarat sig. a hasil perhitungan $>0,050$. Adapun hasil uji normalitas dengan Kolmogorov-Smirnov Test adalah sebagai berikut:

\begin{tabular}{l}
\hline Tabel 12. Kolmogorov-Smirnov Test Untuk Hasil Uji Normalitas \\
\hline \\
\hline \\
\cline { 2 - 7 }
\end{tabular}

Berdasarkan hasil uji di atas yang menggunakan Kolgmogorov-smirnnov test, diperoleh nilai signifikansinya adalah $\alpha=$ 0,200 dimana nilai tersebut lebih besar dari nilai 0,050. Maka asumsi distribusi persamaan pada uji ini adalah terdistribusi normal.

\section{b. Uji Multikolinieritas}

Untuk mendeteksi ada tidaknya multikolinieritas, dapat dilihat dari tolerance value atau variance Inflation Factor (VIF) dengan ketentuan sebagai berikut:

1. "Jika nilai VIF $>10$ dan nilai tolerance $>$ 1 maka terjadi multikolinieritas"

2. "Jika nilai VIF $<10$ dan nilai tolerance $<$ 1 maka tidak terjadi multikolinieritas"

Hasil pengujian multikolinieritas pada penelitian ini adalah sebagai berikut:

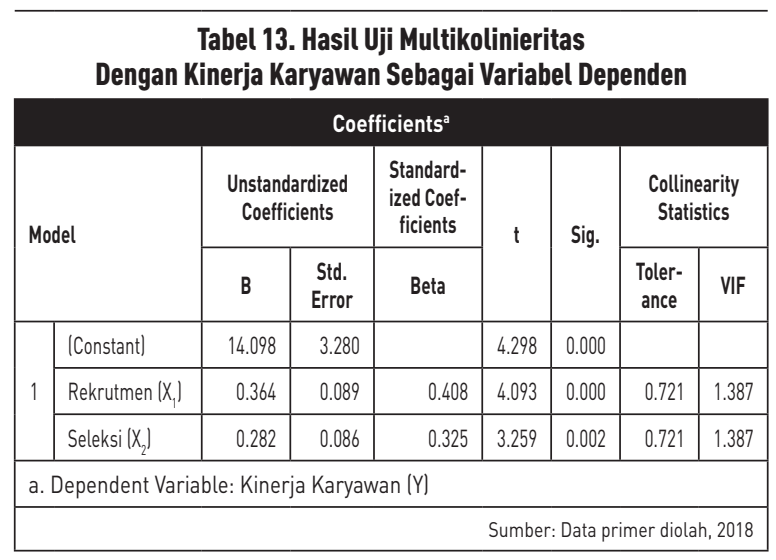

Berdasarkan tabel 13 di atas, model regresi ini tidak terjadi multikoinieritas dimana diperoleh nilai tolerance variabel rekrutmen $\left(\mathrm{X}_{1}\right)$ dan seleksi $\left(\mathrm{X}_{2}\right)$ sebesar 0,721 dimana masing-masing variabel bernilai tolerance kurang dari 1 dan nilai Variance Inflation Factor (VIF) untuk variabel rekrutmen $\left(\mathrm{X}_{1}\right)$ dan seleksi $\left(\mathrm{X}_{2}\right)$ sebesar 1,387 masing-masing nilai VIF kurang dari 10.

\section{c. Uji Heteroskedastisitas}

Langkah selanjutnya adalah menguji apakah ada ketidaksamaan varian residual dari satu pengamatan ke pengamatan lain. Berikut adalah hasil uji heteroskedastisitas dapat dilihat pada gambar 1 dibawah ini:

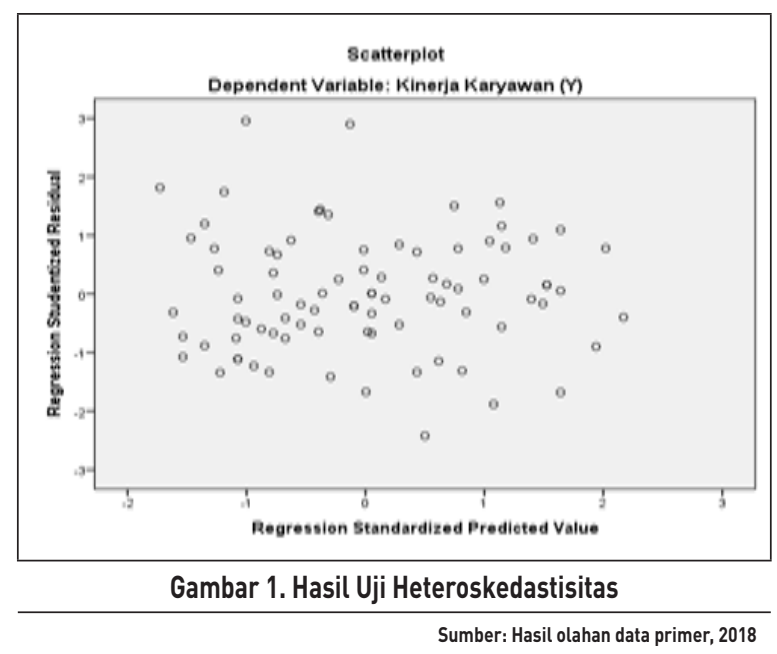

Pada gambar 1 menunjukkan tidak adanya gangguan heteroskedastisitas dimana terlihat titik-titik pada grafik scatter plot tidak mempunyai pola penyebaran yang jelas dan titik-titik tersebut menyebar di atas dan dibawah angka 0 pada sumbu Y.

\section{Analisis Verifikatif}

Untuk mengetahui besaran pengaruh variabel independen terhadap variabel dependen dan menganalisis signifikansi dari pengaruh tersebut maka diperlukan analisis verifikatif. Adapun hasil analisis sebagai berikut:

\section{a. Analisis Regresi Linier Berganda}

Adapun hasil analisis regresi linier berganda sebagai berikut : 


\begin{tabular}{|c|c|c|c|c|c|c|}
\hline \multicolumn{7}{|c|}{$\begin{array}{l}\text { Tabel 14. Hasil Pengolahan Regresi Linier Berganda } \\
\text { Variabel Rekrutmen }\left(X_{1}\right) \text { dan Seleksi }\left(X_{2}\right)\end{array}$} \\
\hline \multicolumn{7}{|c|}{ Coefficients $^{a}$} \\
\hline \multirow{2}{*}{\multicolumn{2}{|c|}{ Model }} & \multicolumn{2}{|c|}{$\begin{array}{l}\text { Unstandardized Coef- } \\
\text { ficients }\end{array}$} & \multirow{2}{*}{$\begin{array}{c}\begin{array}{c}\text { Stan- } \\
\text { dardized } \\
\text { Coef- } \\
\text { ficients }\end{array} \\
\text { Beta }\end{array}$} & \multirow[t]{2}{*}{$t$} & \multirow[t]{2}{*}{ Sig. } \\
\hline & & B & $\begin{array}{l}\text { Std. } \\
\text { Error }\end{array}$ & & & \\
\hline \multirow{3}{*}{1} & (Constant) & 14.098 & 3.280 & & 4.298 & 0.000 \\
\hline & Rekrutmen $\left(X_{1}\right)$ & 0.364 & 0.089 & 0.408 & 4.093 & 0.000 \\
\hline & Seleksi $\left(X_{2}\right)$ & 0.282 & 0.086 & 0.325 & 3.259 & 0.002 \\
\hline \multicolumn{7}{|c|}{ a. Dependent Variable: Kinerja Karyawan (Y) } \\
\hline & & & & er: $: \mathrm{H}$ & dat & er, 2018 \\
\hline
\end{tabular}

Dari hasil persamaan regresi linier berganda tersebut dengan persamaan $\mathrm{Y}=14,098$ $+0,364 \mathrm{X}_{1}+0,282 \mathrm{X}_{2}$, maka dapat disimpulkan sebagai berikut:

1. "Nilai konstanta sebesar 14,098 menyatakan bahwa jika nilai variabel rekrutmen $\left(\mathrm{X}_{1}\right)$ dan seleksi $\left(\mathrm{X}_{2}\right)$ tidak ada atau $=$ 0, maka nilai kinerja karyawan adalah sebesar 14,098."

2. "Koefisien regresi variabel rekrutmen $\left(\mathrm{X}_{1}\right)$ 0,364, artinya setiap penambahan 1 (satu) poin variabel rekrutmen, maka hal itu akan meningkatkan kinerja karyawan sebesar 0,364 kali."

3. "Koefisien regresi variabel seleksi $\left(\mathrm{X}_{2}\right)$ 0,282 , artinya setiap penambahan 1 (satu) poin variabel seleksi, maka akan meningkatkan kinerja karyawan sebesar 0,282 kali."

Berdasarkan persamaan di atas adalah koefisien regresi variabel rekrutmen $\left(\mathrm{X}_{1}\right)$ 0,364 dan seleksi $\left(\mathrm{X}_{2}\right)$ 0,282, dapat diartikan bahwa rekrutmen dan seleksi searah dengan variabel kinerja karyawan. Dengan kata lain bahwa dengan adanya proses rekrutmen yang baik maka akan semakin baik pula kinerja yang dihasilkan oleh karyawan. Serta dengan seleksi yang baik maka akan dapat menghasilkan karyawan yang benar-benar sesuai dengan kebutuhan perusahaan.

\section{b. Analisis Koefisien Korelasi}

Berikut adalah hasil analisis koefisien korelasi dapat dilihat pada tabel 15 dibawah ini:

\begin{tabular}{|c|c|c|c|}
\hline \multicolumn{4}{|c|}{$\begin{array}{l}\text { Tabel 15. Hasil Analisis Koefisien Kore } \\
\text { Variabel Rekrutmen }\left(X_{1}\right) \text { Terhadap Kir }\end{array}$} \\
\hline \multicolumn{4}{|c|}{ Coefficients $^{\mathrm{a}}$} \\
\hline & & Rekrutmen $\left(X_{1}\right)$ & $\begin{array}{c}\text { Kinerja } \\
\text { Karyawan (Y) }\end{array}$ \\
\hline \multirow{3}{*}{ Rekrutmen $\left(X_{1}\right)$} & Pearson Correlation & 1 & $.580^{* *}$ \\
\hline & Sig. (2-tailed) & & 0.000 \\
\hline & $\mathrm{N}$ & 85 & 85 \\
\hline \multirow{3}{*}{$\begin{array}{l}\text { Kinerja } \\
\text { Karyawan (Y) }\end{array}$} & Pearson Correlation & $.580^{* *}$ & 1 \\
\hline & Sig. (2-tailed) & 0.000 & \\
\hline & $\mathrm{N}$ & 85 & 85 \\
\hline \multicolumn{4}{|c|}{ **. Correlation is significant at the 0.01 level (2-tailed). } \\
\hline & & \multicolumn{2}{|c|}{ Sumber : Hasil olahan data primer, 2018.} \\
\hline
\end{tabular}

Berdasarkan tabel 15 Analisis koefisien korelasi diperlukan untuk mengetahui tingkat kekuatan pengaruh atau hubungan antara variabel independen terhadap variabel dependen baik secara parsial maupun simultan. Dari tabel di atas diperoleh nilai koefisien korelasi sebesar 0,580. Artinya variabel rekrutmen $\left(\mathrm{X}_{1}\right)$ memiliki tingkat kekuatan hubungan yang sedang terhadap kinerja karyawan $(\mathrm{Y})$.

\begin{tabular}{|c|c|c|c|}
\hline \multicolumn{4}{|c|}{$\begin{array}{l}\text { Tabel 16. Hasil Analisis Koefisien Korelasi (Secara Parsial) } \\
\text { Variabel Seleksi (X) Terhadap Kinerja Karyawan (Y) }\end{array}$} \\
\hline \multicolumn{4}{|c|}{ Coefficients $^{a}$} \\
\hline & & Seleksi $\left(X_{2}\right)$ & $\begin{array}{c}\text { Kinerja } \\
\text { Karyawan }(Y)\end{array}$ \\
\hline \multirow{3}{*}{ Seleksi $\left(X_{2}\right)$} & Pearson Correlation & 1 & $.540^{* *}$ \\
\hline & Sig. (2-tailed) & & 0.000 \\
\hline & $\mathrm{N}$ & 85 & 85 \\
\hline \multirow{3}{*}{$\begin{array}{l}\text { Kinerja } \\
\text { Karyawan (Y) }\end{array}$} & Pearson Correlation & $.540^{* *}$ & 1 \\
\hline & Sig. (2-tailed) & 0.000 & \\
\hline & $\mathrm{N}$ & 85 & 85 \\
\hline \multicolumn{4}{|c|}{ **. Correlation is significant at the 0.01 level (2-tailed). } \\
\hline & & \multicolumn{2}{|c|}{ Sumber : Hasil olahan data primer, 2018.} \\
\hline
\end{tabular}

Berdasarkan tabel 16 di atas, nilai koefisien korelasi sebesar 0,540. Maka antara variabel seleksi $\left(\mathrm{X}_{2}\right)$ memiliki tingkat kekuatan hubungan yang sedang terhadap kinerja karyawan (Y).

\begin{tabular}{|c|c|c|c|c|}
\hline \multicolumn{5}{|c|}{$\begin{array}{l}\text { Tabel 17. Hasil Analisis Koefisien Korelasi (Secara Simultan) } \\
\text { Variabel Rekrutmen }\left(\mathrm{X}_{1}\right) \text { dan Seleksi }\left(\mathrm{X}_{2}\right) \\
\text { Terhadap Kinerja Karyawan }(\mathrm{Y})\end{array}$} \\
\hline \multicolumn{5}{|c|}{ Model Summary } \\
\hline Model & $\mathbf{R}$ & R Square & $\begin{array}{l}\text { Adjusted } \\
\text { R Square }\end{array}$ & $\begin{array}{l}\text { Std. Error of the } \\
\text { Estimate }\end{array}$ \\
\hline 1 & $.642^{\mathrm{a}}$ & 0.412 & 0.398 & 2.946 \\
\hline \multicolumn{5}{|c|}{ a. Predictors: (Constant), Seleksi ( $\left.\mathrm{X}_{2}\right)$, Rekrutmen $\left(\mathrm{X}_{1}\right)$} \\
\hline \multicolumn{5}{|c|}{ Sumber : Hasil olahan Data primer, 2018} \\
\hline
\end{tabular}


Berdasarkan tabel 17 nilai koefisien korelasi sebesar 0,642. Maka variabel rekrutmen $\left(\mathrm{X}_{1}\right)$ dan seleksi $\left(\mathrm{X}_{2}\right)$ secara simultan memiliki tingkat kekuatan hubungan yang kuat terhadap kinerja karyawan $(\mathrm{Y})$.

\section{c. Analisis Koefisien Determinasi}

Mengetahui persentase pengaruh variabel independen terhadap variabel dependen baik secara parsial maupun secara simultan diperlukan analisis koefisien determinasi. Dalam analisis ini digunakan rumus $\mathrm{KD}=$ $\mathrm{R}^{2} \times 100 \%$. Hasil analisinya adalah sebagai berikut:

Tabel 18. Hasil Pengolahan Data Koefisien Determinasi
(Secara Parsial) Variabel Rekrutmen (X)
Terhadap Variabel Kinerja Karyawan (Y)
Model Summary

Nilai koefisien determinasi pada $R$ square sebesar 0,336. Sehingga variabel rekrutmen $\left(\mathrm{X}_{1}\right)$ memiliki kontribusi pengaruh terhadap variabel kinerja karyawan (Y) sebesar 33.6\%.

\begin{tabular}{|c|c|c|c|c|}
\hline \multicolumn{5}{|c|}{$\begin{array}{l}\text { Tabel 19. Hasil Pengolahan Data Koefisien Determinasi } \\
\text { (Secara Parsial) Variabel Seleksi (X) } \\
\text { Terhadap Variabel Kinerja Karyawan (Y) }\end{array}$} \\
\hline \multicolumn{5}{|c|}{ Model Summary } \\
\hline Model & $\mathbf{R}$ & R Square & $\begin{array}{l}\text { Adjusted } \\
\text { R Square }\end{array}$ & $\begin{array}{l}\text { Std. Error of the } \\
\text { Estimate }\end{array}$ \\
\hline 1 & $.540^{\mathrm{a}}$ & 0.292 & 0.284 & 3.214 \\
\hline \multicolumn{5}{|c|}{ a. Predictors: (Constant), Seleksi $\left(X_{2}\right)$} \\
\hline \multicolumn{5}{|c|}{ Sumber : Hasil olahan Data primer, 201} \\
\hline
\end{tabular}

Nilai koefisien determinasi pada $R$ Square sebesar 0,292. Sehingga variabel seleksi $\left(\mathrm{X}_{2}\right)$ memiliki kontribusi pengaruh terhadap variabel kinerja karyawan $(\mathrm{Y})$ sebesar $29,2 \%$.

\begin{tabular}{|c|c|c|c|c|}
\hline \multicolumn{5}{|c|}{$\begin{array}{l}\text { Tabel 20. Hasil Analisis Koefisien Determinasi (Secara Simultan) } \\
\text { Variabel Rekrutmen }\left(X_{1}\right) \text { dan Seleksi ( } X_{2} \text { ) } \\
\text { Terhadap Variabel Kinerja Karyawan (Y) }\end{array}$} \\
\hline \multicolumn{5}{|c|}{ Model Summary ${ }^{b}$} \\
\hline Model & R & R Square & $\begin{array}{l}\text { Adjusted } \\
\text { R Square }\end{array}$ & $\begin{array}{l}\text { Std. Error of the } \\
\text { Estimate }\end{array}$ \\
\hline 1 & $.642^{\mathrm{a}}$ & 0.412 & 0.398 & 2.946 \\
\hline \multicolumn{5}{|c|}{ a. Predictors: (Constant), Seleksi ( $\left.X_{2}\right)$, Rekrutmen $\left(X_{1}\right)$} \\
\hline \multicolumn{5}{|c|}{ Sumber : Hasil olahan Data primer, 2018} \\
\hline
\end{tabular}

Nilai koefisien determinasi (R-Square) sebesar 0,412. Bisa dikatakan rekrutmen $\left(\mathrm{X}_{1}\right)$ dan seleksi $\left(\mathrm{X}_{2}\right)$ secara bersama-sama memiliki kontribusi pengaruh terhadap kinerja karyawan (Y) sebesar 41,2\%.

\section{d. Pengujian Hipotesis}

1. Pengujian Hipotesis Secara Parsial (Uji Statistik t)

"Pengujian hipotesis secara parsial dimaksudkan untuk menguji secara stastistik (uji t) apakah rumusan hipotesis yang dibuat diterima atau ditolak. Pengujian pengaruh dalam penelitian ini antara variabel independen terhadap variabel dependen secara parsial."

"Signifikansi dalam penelitian ini digunakan 5\% $(0,05)$ dengan membandingkan $\mathrm{t}_{\text {hitung }}$ dengan $\mathrm{t}_{\text {tabel }}$ dengan kriteria sebagai berikut":

a. "Jika $\mathrm{t}_{\text {hitung }}>\mathrm{t}_{\text {tabel" }}$ maka H0 ditolak dan H1 diterima."

b. "Jika $\mathrm{t}_{\text {hitung }}<\mathrm{t}_{\text {tabel }}$, maka H0 diterima dan H1 ditolak."

"Besarnya nilai $\mathrm{t}_{\text {tabel }}$ dicari dengan menggunakan rumus berikut ini “:

$" \mathrm{t}_{\text {tabel }}=$ ta.df (Taraf Alpha $\mathrm{x}$ Degree of Freedom)"

“ $\alpha=$ tarif nyata 5\%"

"df $=(n-2)$, maka diperoleh $(85-2)=83 "$

" $\mathrm{t}_{\text {tabel }}=1,989 "$

a. Pengaruh Rekrutmen $\left(\mathrm{X}_{1}\right)$ Terhadap Kinerja Karyawan (Y)

Rumusan hipotesisnya:

" $\mathrm{H}_{0}: \rho=0$ Tidak terdapat pengaruh positif dan signifikan antara rekrutmen terhadap kinerja karyawan secara parsial."

"H† : $\rho \neq 0$ Terdapat pengaruh positif dan signifikan antara rekrutmen terhadap kinerja karyawan secara parsial."

Adapun hasil pengujian hipotesis tersebut di atas, sebagai berikut:

Tabel 21 menunjukkan nilai $\mathrm{t}_{\text {hitung }}>\mathrm{t}_{\text {tabel }}$ atau $(6,481>1,989)$ hal ini diperkuat dengan nilai signifikansi 0,000 $<0,05$. Sehingga hipotesis pertama dapat diterima. Yakni terdapat pengaruh yang positif dan signifikan secara 
parsial antara rekrutmen terhadap kinerja karyawan.

\begin{tabular}{|c|c|c|c|c|c|c|}
\hline \multicolumn{7}{|c|}{$\begin{array}{l}\text { Tabel 21. Hasil Uji t Variabel Rekrutmen }\left(X_{1}\right) \\
\text { Terhadap Variabel Kinerja Karyawan }(Y)\end{array}$} \\
\hline \multicolumn{7}{|c|}{ Coefficients $^{\mathrm{a}}$} \\
\hline \multirow{2}{*}{\multicolumn{2}{|c|}{ Model }} & \multicolumn{2}{|c|}{$\begin{array}{l}\text { Unstandardized Coef- } \\
\text { ficients }\end{array}$} & \multirow{2}{*}{$\begin{array}{c}\begin{array}{c}\text { Stan- } \\
\text { dardized } \\
\text { Coef- } \\
\text { ficients }\end{array} \\
\text { Beta }\end{array}$} & \multirow[t]{2}{*}{$\mathrm{t}$} & \multirow[t]{2}{*}{ Sig. } \\
\hline & & B & $\begin{array}{c}\text { Std. } \\
\text { Error }\end{array}$ & & & \\
\hline \multirow{2}{*}{1} & (Constant) & 18.866 & 3.101 & & 6.083 & 0.000 \\
\hline & Rekrutmen $\left(X_{1}\right)$ & 0.516 & 0.080 & 0.580 & 6.481 & 0.000 \\
\hline \multicolumn{7}{|c|}{ a. Dependent Variable: Kinerja Karyawan (Y) } \\
\hline
\end{tabular}

b. Pengaruh Seleksi $\left(\mathrm{X}_{2}\right)$ Terhadap Kinerja Karyawan (Y)

Rumusan hipotesisnya:

" $\mathrm{H}_{0}: \rho=0$ Tidak terdapat pengaruh positif dan signifikan antara seleksi terhadap kinerja karyawan secara parsial."

" $\mathrm{H}_{2}: \rho \neq 0$ Terdapat pengaruh positif dan signifikan antara seleksi terhadap kinerja karyawan secara parsial."

Adapun hasil pengujian hipotesis tersebut di atas sebagai berikut:

\begin{tabular}{|c|c|c|c|c|c|c|}
\hline \multicolumn{7}{|c|}{$\begin{array}{l}\left.\text { Tabel 22. Hasil Uji t Variabel Seleksi ( } X_{2}\right) \\
\text { Terhadap Kinerja Karyawan (Y) }\end{array}$} \\
\hline \multicolumn{7}{|c|}{ Coefficients $^{\mathrm{a}}$} \\
\hline \multirow{2}{*}{\multicolumn{2}{|c|}{ Model }} & \multicolumn{2}{|c|}{$\begin{array}{l}\text { Unstandardized Coef- } \\
\text { ficients }\end{array}$} & \multirow{2}{*}{$\begin{array}{c}\begin{array}{c}\text { Stan- } \\
\text { dardized } \\
\text { Coef- } \\
\text { ficients }\end{array} \\
\text { Beta }\end{array}$} & \multirow[t]{2}{*}{$t$} & \multirow[t]{2}{*}{ Sig. } \\
\hline & & B & $\begin{array}{l}\text { Std. } \\
\text { Error } \\
\end{array}$ & & & \\
\hline \multirow{2}{*}{1} & (Constant) & 21.079 & 3.056 & & 6.897 & 0.000 \\
\hline & Seleksi $\left(X_{2}\right)$ & 0.468 & 0.080 & 0.540 & 5.852 & 0.000 \\
\hline \multicolumn{7}{|c|}{ a. Dependent Variable: Kinerja Karyawan (Y) } \\
\hline
\end{tabular}

Tabel 22 menunjukkan nilai $\mathrm{t}_{\text {hitung }}>\mathrm{t}_{\text {tabel }}$ atau $(5,852>1,989)$ hal ini diperkuat dengan nilai signifikansi $0,000<0,05$. untuk itu hipotesis kedua dapat diterima. Yakni terdapat pengaruh yang positif dan signifikan secara parsial antara seleksi terhadap kinerja karyawan.

2. Pengujian Hipotesis Secara Simultan (Uji F)

Pengujian hipotesis secara simultan dimaksudkan untuk mengetahui pengaruh variabel rekrutmen $\left(\mathrm{X}_{1}\right)$ dan seleksi $\left(\mathrm{X}_{2}\right)$ ter- hadap variabel kinerja karyawan (Y) dapat dilakukan dengan uji statistic $\mathrm{F}$ (uji simultan). Signifikansi dalam penelitian ini digunakan $5 \%(0,05)$ dengan membandingkan $\mathrm{F}_{\text {hitung }}$ dengan $\mathrm{F}_{\text {tabel }}$ dengan kriteria sebagai berikut:

a. Jika $\mathrm{F}_{\text {hitung }}<\mathrm{F}_{\text {tabel }}$ maka $\mathrm{H} 0$ diterima dan H1 ditolak.

b. Jika $\mathrm{F}_{\text {hitung }}>\mathrm{F}_{\text {tabel }}$ maka $\mathrm{H} 0$ ditolak dan H1 diterima.

Besarnya $\mathrm{F}_{\text {tabel }}$ dicari dengan ketentuan: $(n-2-1)$, maka diperoleh $(85-2-1)=82$, sehingga $\mathrm{F}_{\text {tabel }}=3,110$. Adapun rumusan hipotesisnya adalah:

" $\mathrm{H}_{0}: \rho 1,2=0$ Tidak terdapat pengaruh positif dan signifikan antara rekrutmen dan seleksi terhadap kinerja karyawan secara simultan."

" $\mathrm{H}_{2}: \rho 1,2 \neq 0$ Terdapat pengaruh positif dan signifikan antara rekrutmen dan seleksi terhadap kinerja karyawan secara simultan."

Adapun hasil pengujian hipotesis tersebut di atas, sebagai berikut:

\begin{tabular}{|c|c|c|c|c|c|c|}
\hline \multicolumn{7}{|c|}{$\begin{array}{l}\text { Tabel 23. Hasil Uji F Variabel Rekrutmen }\left(X_{1}\right) \text { dan Seleksi }\left(X_{2}\right) \\
\text { Secara Simultan Terhadap Variabel Kinerja Karyawan }(Y)\end{array}$} \\
\hline & IOVA & & & \\
\hline \multicolumn{2}{|c|}{ Model } & $\begin{array}{l}\text { Sum of } \\
\text { Squares }\end{array}$ & Df & $\begin{array}{l}\text { Mean } \\
\text { Square }\end{array}$ & $F$ & Sig. \\
\hline \multirow{3}{*}{1} & Regression & 499.109 & 2 & 249.555 & 28.745 & $.000^{b}$ \\
\hline & Residual & 711.903 & 82 & 8.682 & & \\
\hline & Total & 1211.012 & 84 & & & \\
\hline \multicolumn{7}{|c|}{ a. Dependent Variable: Kinerja Karyawan (Y) } \\
\hline \multicolumn{7}{|c|}{ b. Predictors: (Constant), Seleksi ( $\left.X_{2}\right)$, Rekrutmen $\left(X_{1}\right)$} \\
\hline
\end{tabular}

Tabel 23 menunjukkan nilai $\mathrm{F}_{\text {hitung }}>\mathrm{F}_{\text {tabel }}$ atau $(28,745>3,110)$ hal ini juga diperkuat dengan nilai probability signifikansi sebesar $0,000<0,05$. Dengan demikian hipotesis ke tiga dapat diterima. Yakni terdapat pengaruh yang positif dan signifikansi secara bersamasama antara variabel rekrutmen dan seleksi terhadap kinerja karyawan.

\section{Pembahasan Penelitian}

Setelah peneliti melakukan analisis korelasi dengan menggunakan program SPSS 24. Maka akan didapatkan koefisien korelasi dan juga 
nilai signifikansi. Untuk mengetahui keeratan hubungan maka dapat dilihat pada besarnya koefisien korelasi beganda dengan pedoman: jika koefisien semakin mendekati nilai 1 atau -1 maka hubungan yang ada yaitu erat atau kuat, sedangkan jika koefisien semakin mendekati angka 0 , maka hubungan lemah.

Sedangkan untuk mengetahui hubungan positif berbanding lurus/negatif berbanding terbalik dapat dilihat pada nilai koefisien korelasi, yakni tanda positif/negatif. Jika tandanya positif maka terdapat hubungan yang positif, sebaliknya jika tanda negatif maka terdapat hubungan negatif. Berdasarkan uji hipotesis penelitian dari data-data yang telah disajikan di atas, maka dilakukan pembahasan penelitian. Hasil-hasil penelitian tersebut diantaranya adalah sebagai berikut:

\section{Rekrutmen $\left(\mathrm{X}_{1}\right)$}

Dari hasil jawaban 85 responden yang menjadi objek penelitian. Ditemukan hasil" nilai rata-rata sebesar 3,87 ada pada interval 3,40 4,19" dengan kategori "Baik".

Berdasarkan data tabel 6, dapat dilihat bahwa dari 10 butir pernyataan untuk variabel rekrutmen $\left(\mathrm{X}_{1}\right)$ semua butir pernyataan dinyatakan valid, dimana semua item pernyataan memiliki nilai corrected item total correlation lebih besar dari 0,213 atau $\mathrm{r}_{\text {hitung }}>\mathrm{r}_{\text {tabel }}$

Berdasarkan hasil uji reliabilitas pada tabel 9 , disimpulkan reliabel, hal itu dibuktikan dengan nilai $r_{\text {hitung }}>r_{\text {tabel }}(0,213)$. Dengan demikian data layak untuk diteruskan pada penelitian ini.

Sedangkan untuk pembuktian hipotesis, hasil menunjukkan bahwa terdapat pengaruh yang positif dan signifikan antara rekrutmen dengan kinerja karyawan. Hasil diperoleh nilai $\mathrm{t}_{\text {hitung }}>\mathrm{t}_{\text {tabel }}$ atau $(6,481>1,989)$ hal ini diperkuat dengan nilai signifikansi $0,000<0,05$. Sehingga hipotesis pertama dapat diterima dimana terdapat pengaruh yang positif dan signifikan secara parsial antara rekrutmen terhadap kinerja karyawan di PT Trinitas Mulia Abadi di Jakarta Utara.

\section{Seleksi (X2)}

Dari hasil jawaban 85 responden yang menjadi objek penelitian terkait seleksi, ditemukan hasil "nilai rata-rata sebesar 3,79 ada pada interval 3,40 - 4,19" dengan kategori "Baik".

Berdasarkan data tabel 7, dapat dilihat bahwa dari 10 butir pernyataan untuk variabel seleksi $\left(\mathrm{X}_{2}\right)$ disimpulkan bahwa semua butir pernyataan dinyatakan valid, hal ini dibuktikan dengan semua item-item pernyataan memiliki nilai corrected item total correlation lebih besar dari nilai $\mathrm{r}_{\text {tabel }}$ 0,213 . Untuk itu kuesioner yang digunakan layak untuk diolah data penelitian

Berdasarkan data tabel 10, dapat dilihat bahwa dari 10 butir pernyataan untuk variabel seleksi $\left(\mathrm{X}_{2}\right)$ semua butir pernyataan dinyatakan reliabel, dimana semua item pernyataan memiliki nilai $\mathrm{r}_{\text {hitung }}>\mathrm{r}_{\text {tabel }}(0,213)$.

Kemudian hasil analisis uji hipotesis untuk variabel yang kedua yaitu seleksi $\left(\mathrm{X}_{2}\right)$ terhadap kinerja (Y) menunjukkan terdapat pengaruh yang positif dan signifikan antara seleksi dengan kinerja karyawan. Hasil yang diperoleh adalah nilai $t_{\text {hitung }}>$ $t_{\text {tabel }}$ atau $(5,852>1,989)$, hal ini diperkuat dengan nilai signifikansi $0,000<0,05$. Sehingga hipotesis kedua dapat diterima dimana terdapat pengaruh yang positif dan signifikan secara parsial antara seleksi terhadap kinerja karyawan di PT Trinitas Mulia Abadi di Jakarta Utara.

\section{Kinerja Karyawan (Y)}

Berdasarkan hasil analisis jawaban dari 85 responden yang menjadi objek penelitian, hasil diperoleh "nilai rata-rata sebesar 3,88 ada pada interval 3,40 - 4,19" dengan kategori "Baik".

Berdasarkan data tabel 8, dapat dilihat bahwa dari 10 butir pernyataan untuk variabel kinerja karyawan (Y) semua butir pernyataan dinyatakan valid, hal ini dibuktikan dengan semua item pernyataan memiliki nilai $\mathrm{r}_{\text {hitung }}>\mathrm{r}_{\text {tabel }}(0,213)$.

Berdasarkan hasil pengolahan data tabel 11 , diketahui bahwa masing-masing item pernyataan variabel kinerja karyawan (Y) memiliki nilai $r_{\text {hitung }}>r_{\text {tabel }}(0,213)$. Dengan demikian instrument dinyatakan reliabel.

Sedangkan hasil uji secara simultan diperoleh hasil nilai $\mathrm{F}_{\text {hitung }}>\mathrm{F}_{\text {tabel }}$ atau $(28,745>3,110)$, dengan nilai probability signifikansi sebesar 0,000 $<0,05$. Dapat disimpulkan bahwa hipotesis ke tiga 
juga dapat diterima, dimana terdapat pengaruh yang positif dan signifikansi secara bersama-sama antara variabel rekrutmen dan seleksi terhadap kinerja karyawan di PT. Trinitas Mulia Abadi di Jakarta Utara.

\section{SIMPULAN}

Berdasarkan pada hasil penelitian dengan menggunakan uji $t$ untuk variabel rekrutmen $\left(\mathrm{X}_{1}\right)$ maka diperoleh nilai $\mathrm{t}_{\text {hitung }}>\mathrm{t}_{\text {tabel }}$ atau $(6,481>$ $1,989)$ hal ini diperkuat dengan nilai signifikansi $0,000<0,05$, dengan demikian dapat dinyatakan bahwa "terdapat pengaruh yang positif dan signifikan antara variabel Rekrutmen $\left(\mathrm{X}_{1}\right)$ terhadap Kinerja (Y)”. Untuk variabel seleksi $\left(\mathrm{X}_{2}\right)$ dari hasil penelitian ini diperoleh nilai $\mathrm{t}_{\text {hitung }}>$ $t_{\text {tabel }}$ atau $(5,852>1,989)$ hal ini diperkuat dengan nilai signifikansi $0,000<0,05$, dengan demikian terdapat "pengaruh yang positif dan signifikan secara parsial antara variabel seleksi $\left(\mathrm{X}_{2}\right)$ terhadap Kinerja (Y)". Sedangkan secara simultan dengan uji $\mathrm{F}$ terdapat "pengaruh yang positif dan signifikan secara bersama-sama antara variabel rekrutmen $\left(\mathrm{X}_{1}\right)$ dan seleksi $\left(\mathrm{X}_{2}\right)$ terhadap kinerja karyawan (Y)" pada PT Trinitas Mulia Abadi Jakarta Utara, dapat dilihat dari nilai $\mathrm{F}_{\text {hitung }}>\mathrm{F}_{\text {tabel }}$ atau $(28,745>3,110)$ hal ini juga diperkuat dengan nilai probability signifikansi sebesar 0,000 $<0,05$. Saran dalam penelitian ini adalah sebaiknya perusahaan melakukan evaluasi untuk jumlah tenaga kerja yang dibutuhkan dan perusahaan juga mempertimbangkan calon karyawan yang memiliki keahlian tertentu.

\section{PENGHARGAAN}

Pada kesempatan kali ini penulis ingin mengucapkan terimakasih kepada semua yang terlibat baik secara langsung maupun tidak langsung yang tidak bisa penulis sebutkan satu persatu. Terimakasih atas saran, masukan, dan bantuan, semoga penelitian ini bisa bermanfaat bagi semua pihak.

\section{DAFTAR PUSTAKA}

Ardana, I. (2012). Manajemen Sumber Daya Manusia. Yogyakarta: Graha Ilmu.
Badriyah, M. (2015). Manajemen Sumber Daya Manusia. Bandung: Pustaka Setia, Cetakan Kesatu.

Dessler, G. (2011). Manajemen Sumber Daya Manusia. Jakarta: PT.Indeks, Edisi Kesepuluh.

Dessler, G. (2015). Manajemen Sumber Daya Manusia. Jakarta: Salemba Empat.

Handoko, T. (2011). Manajemen Personalia dan Sumberdaya Manusia. Yogyakarta: BPFE.

Hasibuan, M. (2011). Manajemen Sumber Daya Manusia. Jakarta: Bumi Aksara.

Hasibuan, M. (2012). Manajemen Sumber Daya Manusia. Jakarta: Bumi Aksara.

Mangkunegara, A. (Manajemen Sumber Daya Manusia Perusahaan). 2011. Bandung: Rosda.

Manullang. (2011). Dasar-Dasar Manajemen. Yogyakarta: Gajah Mada University Press.

Mardianto, A. (2014). Management Recruitment. Jakarta: Pinasthika Publisher.

Marwansyah. (2012). Manajemen Sumber Daya Manusia. Bandung: Alfabeta.

Siagian, S. (2016). Manajemen Sumber Daya Manusia. Jakarta: Bumi Aksara, Edisi satu, Cetakan 24.

Sugiyono. (2011). Metode Penelitian Kuantitatif Kualitatif dan R\& D. Bandung: Alfabeta.

Sugiyono. (2012). Metode Penelitian Bisnis. Bandung: Alfabeta.

Sugiyono. (2013). Metode Penelitian Kuantitatif Kualitatif dan R \& D. Bandung: Alfabeta.

Sugiyono. (2015). Metode Penelitian Kuantitatif Kualitatif dan R\&D. Bandung: Alfabeta, Cetakan Kedua puluh dua.

Sutrisno, E. (2015). Manajemen Sumber Daya Manusia. Jakarta: Kencana Prenada Media Group, Cetakan Ketujuh.

Wibowo. (2012). Manajemen Kinerja. Jakarta: Raja Grafindo Persada.

Wirawan. (2011). Evaluasi Kinerja Sumber Daya Manusia. Jakarta: Salemba Empat.

Zainal, V. \&. (2015). Manajemen Sumber Daya Manusia Untuk Perusahaan: dari Teori ke Praktik. Jakarta: Rajawali Pers, Edisi Ketiga, Cetakan Ketujuh. 